\title{
Mother Tongue Interference in Speaking Arabic of Darul Lugah Waddirasatil Islamiyah Boarding School Santriwati
}

\author{
Khoirul Bariyah ${ }^{1, *}$ Umi Machmudah $^{2}$, Sulalah Sulalah ${ }^{3}$ \\ ${ }^{1}$ Islamic State University of Maulana Malik Ibrahim Malang, Indonesia \\ ${ }^{2}$ Islamic State University of Maulana Malik Ibrahim Malang, Indonesia \\ ${ }^{3}$ Islamic State University of Maulana Malik Ibrahim Malang, Indonesia \\ *Corresponding Author. Email: kbariyah91@gmail.com
}

\begin{abstract}
Darul Lughah Waddirasatil Islamiyah is obligated to use the Arabic language, but santriwati always make mistakes by interfering with the Madurese language, their mother tounge. The researcher, therefore, will analyze and describe interference, the element of interference, and the solution of mistakes. The method of research is descriptive analysis with a qualitative approach. The instruments of research are interviews, observation, and documentation. Then, the data are analyzed with Milles and Huberman's theory. The research results show that the form of interference of mother tongue at Boarding School Darul Lugah Waddirasatil Islamiyah is the interference of phonology, morphology, syntax, and semantic interference and interference lexical. Interference problems are the weakness of the supervisor, lack of mufrodat and qowaid, and forced speaking the Arabic language without a supervisor. The interference solutions are observation, mufrodat and qowaid, and listening to a native speaker speaking Arabic.
\end{abstract}

Keywords: Interference of language, Speaking Skill, Interference of Mother Tongue to Speaking Skill

\section{INTRODUCTION}

Arabic is a world language that has been widely studied and has become an international language widely used in various literary sources. In addition, Arabic is also often said to have an extensive library in all fields of science [1]. However, Arabic teaching has differences with other sciences as teaching Arabic prioritize language skilss consisting of four skills, listening skills (istima'), speaking skills (kalam), reading skills (qiroah), and writing skills (kitabah).

The thing that is most concerned is speaking Arabic is called as maharah kalam. Several things support a person's ability to speak Arabic: mastery of mufrodat, courage to pronounce even though it is wrong, and friends or language environment [2].

Maharah kalam is a speaking skill. The definition of maharah kalam from linguists varies. It is said that maharah kalam is the ability to convey messages orally. Another opinion says that speaking skills are the ability to reproduce articulations used to convey feelings, desires, and wishes to others [3].

Speaking skills is usually referred to as ta'bir. The two terms are the same but also contain differences. Maharah kalam focuses on oral abilities, while ta'bir tends to express written words. The similarity between the two terms is that they are both active, which function to convey 
the contents of the mind [4]. There are two kinds of speaking skills, Muhadatsah (conversation) and ta'bir Syafahi (verbal expressions) [5]. Moreover, the important parts of maharah kalam are pronunciation, vocabulary or mufrodat and grammar or qowaid [6].

Many of us are bilingual and it suggests that people in the world use two languages as communication tools for different purposes; for example, Madurese, who are learning Arabic, would be able to speak Madurese and Arabic as their second language [7]. In addition, it means a bilingual speaks one language after another, sometimes in shifts.

One of the supporters of speaking Arabic is having the courage to say it even though it is wrong. Unfortunately, some errors usually occur in these supports' speaking skills. It can often happen because of differences in Arabic and mother tongue characters. Many students or teachers are contaminated or interfere with their mother tongue in speaking Arabic.

In bilingualism study, there is an easy language interference. The use of grammar and the first language elements of a second language differs from a person learning a first language with no interference language [8]. Learners will transfer the first language when the second language is used. In sociolinguistics studies, the result was called interference, code-mixing and errors [9].

The term interference was first used to refer to a change in the language system in connection with the contact of the language with other language elements carried out by bilingual speakers [10]. Then, it is said that interference means mutual influence between languages [11]. The influence is in its simplest form in the form of taking one element from one language and used in conjunction with another language. Haugen also states that language interference or influence occurs due to language contact in a simple form, taking one element from one language and being used in another language [12].

Meanwhile, interference refers to two very different linguistic phenomena. First, a phenomenon that stems from psychology, and the second stems from sociolinguistics. Psychologists use the term interference to refer to old habits' effect on learning new habits. In addition, sociolinguists use interference to refer to language interactions, such as linguistic borrowing and language switching that occur when two language communities are in an interference situation [13].

Interference is normal for bilinguals, as they speak two different languages daily and tend to bring elements of their first language to the second language[14]. Therefore, the language interference for billingualis is a language error that must be considered and finished to be used properly. Language interference is a big deal with santri of boarding schools, especially boarding schools that employ a foreign language such as Arabic as a second language.

Things like this are similar to what happened in one of the Arabic-based Islamic boarding schools in Madura, which must speak Arabic every day, namely Islamic boarding school Darul Lughah Waddirasatil Islamiyah, which is located in Pamekasan of Madura.

As previously explained, Islamic Boarding Darul Lughah Waddirasatil Islamiyah School is an Arabic-based Islamic Boarding School. In his daily life, both in his muhadasah and when learning occurs, Arabic is used. All students without exception are required to speak Arabic under any circumstances. Concerning what is highlighted in this discussion is the interference of the mother tongue, namely the Madurese language, in the students' language conversations.

The types of language interference are phonological interference, syntactic interference, morphological interference, lexical interference, semantic interference, cultural interference, and paralinguistic interference [15]. Because of the obligation to speak Arabic, there are still many influences from their mother tongue, namely Madurese, which has a more extended frequency than Arabic. Therefore, bilingual students will transfer elements of their first language when using their second language [16]. One example of the form of interference expressed by the Islamic boarding school Darul Lughah Waddirasatil Islamiyah students is (سأرجع منى_منى) it means I will go home another time, which is the correct Arabic (سأرجع يوماما). The first sentence form is a transfer from Madurese language to elements of Arabic as a second language. Other example is (موجود ماذا) which is taken from the Madurese words "Bedeh Apah?", in Indonesian "Ada apa?", and in English "What Happen?". While in Arabic it means (ماذا حدث).

Not only in the form of sentences, there are various forms of interference, such as phonological interference. There are differences in the pronunciation of Madurace in pronouncing Arabic, for example in the pronunciation of 
the letters "ض", which the Madurese pronounce the

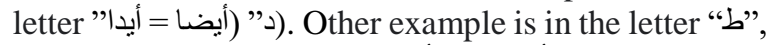
while the Madurese say "(تأستطيع = أستتيع).

Many aspects of interference occur when Arabic language learners, especially speaking skills. The learner will not feel that what is said is wrong because his previous language habits cause it. Therefore, teachers must be sensitive to these events to remind students to minimize interference.

Several factors that cause language interference are important traits of language: the pressure of use, lack of supervision, mastery of the first language and second language, language place, and second language position [17]. Many Arabic language learners in Madura are influenced by language. It is all caused by various factors. The difference between Madurese and Arabic is phonology, morphology, syntax, semantics, or culture, and the use of Arabic in Madura is not as common as in other foreign languages. Arabic language teachers in Madura do not have sufficient experience, both cognitively and professionally. Besides, the school is still poor with modern technology.

Regarding interference, the students of the Islamic boarding school Darul Lughah Waddirasatil Islamiyah still frequently and many do interference due to their lack of vocabulary, then because of their habit of interfering and the weak supervision of the teacher at the Islamic boarding school. Therefore, there is a need for countermeasures to minimize interference in students at the Islamic boarding school Darul Lughah Waddirasatil Islamiyah.

\section{METHOD}

This type of research is field research (Field Research). This study uses a qualitative descriptive approach. A qualitative research method is a method whose research is used to examine the condition of natural objects. This method is used to obtain in-depth data, actual data [18]. Meanwhile, according to Moleong, qualitative research is research that uses a natural setting to interpret the phenomena that occur and is carried out through various existing methods [19].

This qualitative descriptive research consists of two variables: Language Interference and Maharah Kalam. It is used to describe the form of language interference that occurs in female students' conversations at the Islamic Boarding School Darul Lughah Waddirasatil Islamiyah Pamekasan and the causes of language interference and the solutions to these interferences. The presence of researchers in the field at the time of research is vital because researchers act directly to observe research and become data collectors and reporters of research results. The location chosen by the researchers to conduct the research was the female students of the Islamic Boarding School Darul Lughah Waddirasatil Islamiyah.

The data taken at the study was through the triangulation process. Through triangulation, the collection technique is a data collection technique that combines various data collection techniques and existing data sources [20]. Hence, the research uses various data collection techniques, namely observation, interviews, and documentation. Observation is a way of collecting data through observation, accompanied by a record of the state of the behavior of the target object. This observation was carried out by the author coming to the location and participating in various activities of santriwati to find data in the form of interference that occurred in the Islamic boarding school.

Interview is done through a meeting of two people to exchange information and ideas in question and answer, and meaning is constructed in one particular topic. Next, the author uses this interview method to obtain information from the administrators and teachers of the santriwati of the Islamic boarding school Darul Lughah waddirasatil Islamiyah regarding the causes of interference and the solutions for the interference. Last is documentation by recording events that have passed. Documents can be in the form of writing, pictures, or the works of someone. While the data source is the subject from which the data can be obtained [21], the data sources taken in this study were female students, administrators and teachers at the Islamiyah Islamic Boarding School Darul Lughah Waddirasatil Pamekasan Madura.

The data analysis technique used in this study is the Miles and Huberman Model data analysis. Model in analyzing the data starts from data reduction, data display, and conclusion drawing or verification [20]. Data reduction is a sensitive thinking process that requires intelligence and a high breadth and depth of insight. With the reduction, the researcher summarizes, takes the main and important data. After the data is reduced, the next step is to display the data. In qualitative research, data presentation can be done in the form of brief descriptions, charts, relationships between categories, flowcharts, and the like, which is useful in making it easier to understand 
what is happening and plan further work based on what has been understood. According to Miles and Huberman, the third step in data analysis is drawing conclusions and verification.

\section{RESULTS AND DISCUSSION}

From the research results conducted by researchers, researchers obtained data on sentences or words that were included in the category of interference of Mother Language (Madurese) against Arabic. In addition, researchers also obtained data about the factors causing the interference and the solutions for the interference.

\subsection{Forms of Mother Tongue Interference}

After doing the research, the authors get some data about the interference of mother tongue to Arabic that occurs in the speaking skills of students at the Islamic Boarding School Darul Lughah Waddirasatil Islamiyah, the following forms of interference, namely:

\subsubsection{Phonological Interference}

There are two data in phonological interference from the mother tongue (Madura) to Arabic, namely vowels and consonants.

Table 1. The data analysis of consonant phonology

\begin{tabular}{|c|c|c|c|}
\hline No & Interference & Example & \\
\hline 1 & ض=د & أيضا & أيدا \\
\hline 2 & $\tau=\dot{\tau}$ & خمار & حمار \\
\hline 3 & ش=س & أشتري & أستري \\
\hline 4 & ط & أستطيع & أستتيع \\
\hline 5 & ظ= د & نظرت & ندرت \\
\hline
\end{tabular}

From the table, it can be explained that Madurese people find it difficult to distinguish between the letters "ض" with " " " " " " "ح", even so " with", "ط" with" ت" "ط", with" and".
Table 2. Data analysis of vocal phonology

\begin{tabular}{|c|c|c|c|}
\hline No & Interference & Vocal & $\begin{array}{l}\text { Madurese } \\
\text { Language }\end{array}$ \\
\hline 1 & هكذا & Hakadzə & Deyye \\
\hline 2 & ثَوبّه & TsawbbӘh & Kalambinah \\
\hline 3 & ماذا & Madzə & Apah \\
\hline 4 & إيوة لا & lywOh èllak & Yee enjek \\
\hline 5 & مافيه & Mafih & Tadek \\
\hline 6 & لا روه ل ل ل & èllak roh & Enjek roh \\
\hline
\end{tabular}

Pronouncing the letter "a" is same as pronouncing the letter "e" so most of fathah is read "ə", for example "هكذا" would be pronounced "HakadzӘ".

\subsubsection{Morphological Interference}

In Madurese interference, Arabic is obtained by giving an affix at the end of the sentence and it is adjusted to the end of the sentence, for example the word "cantengngah" would be pronounced" مغر فنة ,خز اننة , هكذائن". Besides, there is also a prefix "ter-ater", for example pokol = è+pokol become "è pokol" and suffix "panotèng", for example "kakan+an" become "kakanan".

Reduplication might happen in Madurese "oca 'rangkep" and in Arabic "التكرار". In Madurese, there are initial reduplication ("rangkep aḍâ" (sasamga, root word sanga)), perfect reduplication ("rangkep Bunto" (sokosoko, root word soko)), final reduplication ("Rangkep budil" (tan- taretan, root word taretan)), mixed/mixed reduplication ((èbur-kalèbur, root word lèbur root)), and voice copy reduplication ((rarosak, root word rosak)). The most widely spoken of these various kinds of reduplication are perfect reduplication and final reduplication, for example, "قليل-قليل" (little by little).

\subsubsection{Syntactic Interference}

In syntactic interference might happen since the students do not the correct language order, for examples "I do not want to take bath" is pronounced "ما سأستحم", which in Maduranese is "sengkok tak mandiyeh", while the correct arrangement is" ما أريد استحمام".

\subsubsection{Semantic Interference}

A semantic interference also occurs because of their ignorance or their habit of making their mufrodat. they say "قرد فة " for the word "kerapah (kind of itching)" because they do not know its word in Arabic. 


\subsubsection{Lexical Interference}

Lexical interference is due to the lack or insufficient vocabulary between the two languages, namely Madurese and Arabic. For example, there is no "petis" in Arabic language so they make their own mufrodat "عجين السمك", which is interpreted into "fish starch" as "petis" is made of fish starch.

\subsection{Factors Affecting Mother Tongue Interference}

The following are the factors affecting the interference:

a. Emphasis on use from the start

Arabic has been emphasized from the very beginning to students, even though they have not mastered the Arabic language.

b. Lack of supervision

Lack of supervision from the administrators and teachers will be a factor that affects the occurrence of interference because if it is left unchecked, it will become a habit for them.

c. Mastery of First and Second Language

Lack of practice in speaking Arabic is also one of the factors of the interference so that they will master the first language better than the second language.

\section{d. Language Place}

Islamic Boarding School Darul Lughah is located in Pameksan Madura, so the environment around this Islamic Boarding School is Madura. Therefore, they only speak Arabic if they are in the cottage and it can cause language interference.

e. Minimum vocabulary

Little vocabulary can cause language interference so that little vocabulary will be known and will cause the interference.

\subsection{Solutions for Mother Tongue Interference}

Where there is a problem, that's where the solution comes. And the solution for mother tongue interference on the speaking skills of female students at the Islamic Boarding School Darul Lughah Waddirasatil Islamiyah Pamekasan Madura is as follows:

a. The teachers teach phonological differences in Madurese and Arabic so that they can distinguish sounds from letters that sound similar.

b. The teachers are more intensive in qowaid learning so that there is no more morphological and syntactic interference

c. The teachers familiarize the students to always speak Arabic with the correct qowaid according to what has been taught

d. The students are asked to increase their memorization of vocabulary

e. The teachers supervise and justify the santri's speech that sounds wrong so that it does not become a habit and does not become a hereditary interference.

f. As often as possible, the students are asked to listen to the original nathiq Arabic to imitate them.

\section{CONCLUSION}

Interference is a form of language error caused by the displacement of elements of the first language towards the second language. For example, the interference that occurs in the conversation of female students at the Islamic Boarding School Darul Lughah Waddirasatil Islamiyah Pamekasan Madura is the interference of the mother tongue (Madura) to Arabic. The forms of interference that occur at Islamic Boarding School Darul Lughah Waddirasatil are Phonological Interference, Morphological Interference, syntactic, semantic, and Lexical Interference.

Factors that affect the mother tongue interference in Islamic Boarding School Darul Lughah Waddirasatil Islamiyah are the emphasis from the start, lack of supervision, mastery of the first and second languages, language space, and little vocabulary. The solution for the interferences are increasing the mufrodat treasury, listening to the original nathiq, intensify Arabic qowaid learning, and supervision from teachers. 


\section{REFERENCES}

[1] A. Arsyad, Bahasa Arab dan Pengajarannya, Yogyakarta: Pustaka Pelajar, 2010.

[2] M. A. Mushtofa, 'Interferens Bahasa Indonesia Terhadap Bahasa Arab (Analisis Interferensi dalam pembelajaran maharah kalam)", AnNabighoh, 20(62) (2018) pp.140.

[3] Iskandarwassid, D. Sunendar, Strategi Pembelajaran Bahasa, Bandung: Remaja Rosdakarya, 2011.

[4] S. Mustafa, Strategi Pembelajaran Bahasa Arab Inovatif, Malang: UIN Maliki Press, 2011.

[5] A. W. Rusydi, M. Ni'mah, Memahami Konsep dasar Pembelajaran Bahasa Arab, Malang: UIN Maliki Press, 2011.

[6] A. Mukhlis, Maharah Al-Kalam wa Thariqotu tadrisiha, Pamekasan, STAIN Press, 2009.

[7] H. G. Tarigan, Pengajaran Kedwibahasaan, Bandung: Angkasa, 2009.

[8] S. Mar'at, Psikolinguistik: Suatu Pengantar, Bandung: Refika Aditama, 2015.

[9] A. Chaer, Psikolinguistik: Kajian Teoritik, Jakarta: Rineka Cipta, 2009.

[10] A. Chaer, L. Agustina, Sosiolinguistik Perkenalan Awal, Jakarta: Rineka Cipta, 2010.
[11] Aslinda, L. Syafyahya, Pengantar Sosiolinguistik, Bandung: Refika Aditama, 2014.

[12] Ahmad HP, A. Abdullah, Linguistik Umum, Jakarta: Erlangga, 2012.

[13] I. Adriana, Ilmu al-lugah al-Ijtimaie (sosiolinguistik arab), Malang: Kaben Perdana, 2009.

[14] A. Chaer Al wasilah, Filsafat Bahasa dan Pendidikan, Bandung: REMAJA ROSDAKARYA, 2010.

[15] M. A. Al-Khuli, Al-hayah Ma'a Lugahatain, Riyadh: 1987.

[16] A. Chaer dan L. Agustina, Sosiolinguistik Perkenalan Awal.

[17] Sugiono, Metode Penelitian Pendidikan Pendekatan Kuantitatif, Kualitatif, dan R\&D.

[18] M. A. Dimyati, Muhadaroh Fi Ilmi Lughah AL ijtima'I, Surabaya: Dar al Ulum al Arabiyah, 2010.

[19] Tohirin, Metode Penelitian Kualitatif dalam Pendidikan dan Bimbingan Konseling, Jakarta:PR RajaGrafindo Persada, 2012.

[20] S. Arikunto, Prosedur Penelitian, Jakarta: Pt. Rhineka Cipta, 2002.

[21] M. H. Efendi, "Interferensi Gramatikal Bahasa Madura Ke Dalam Bahasa Indonesia”, Dialektika: Jurnal Bahasa, Sastra, dan Pendidikan bahasa dan sastra Indonesia, 4 (1) (2017) 12-19. 